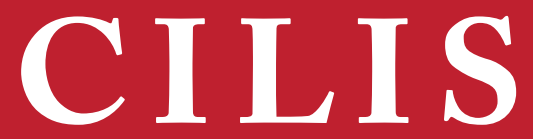

Centre for Indonesian Law, Islam and Society

\section{Policy Paper}

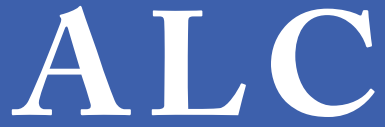

Asian Law Centre

Clemency in Southeast Asian Death Penalty Cases Dr Daniel Pascoe

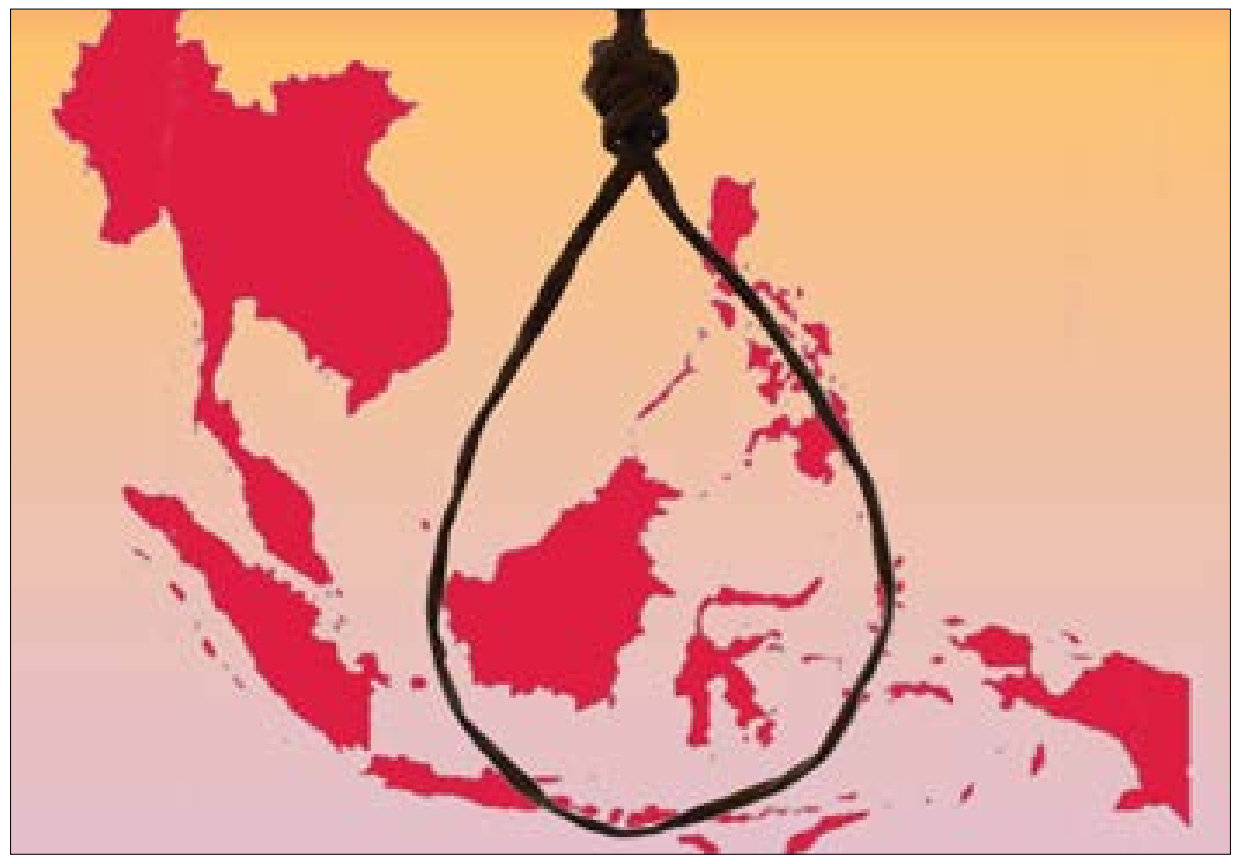

CILIS

ALC

BRIEFING PAPER 


\section{CILIS POLICY PAPERS}

The CILIS Policy Paper Series is edited by Professor Tim Lindsey and Dr Helen Pausacker. It aims to offer policy-makers and the public informed and concise analysis of current issues that involve the Indonesian legal system. They can be downloaded without charge from http://www.law.unimelb. edu.au/cilis/research/centre-publications/cilis-policy-papers

\section{CENTRE FOR INDONESIAN LAW, ISLAM AND SOCIETY}

The Centre for Indonesian Law, Islam and Society (CILIS), located in the Melbourne Law School, was established in 2013. The Director of the Centre is Professor Tim Lindsey, Malcolm Smith Professor of Asian Law in the Melbourne Law School. The Deputy Director is Dr Helen Pausacker, who is also a Principal Researcher in the Asian Law Centre. The Centre Manager is Kathryn Taylor.

The Centre website can be accessed at www.law.unimelb.edu.au/cilis

ISSN 2202-1604 (PRINT)

ISSN 2202-1612 (ONLINE)

2014

\section{ALC BRIEFING PAPERS}

The ALC Briefing Paper Series is edited by Professor Pip Nicholson and Professor Tim Lindsey. It aims to increase understanding of current legal issues arising in the legal systems of Asian countries. They can be downloaded without charge from www.law.unimelb.edu.au/alc/research/ centre-publications/alc-briefing-paper-series

\section{ASIAN LAW CENTRE}

The Asian Law Centre (ALC), located in the Melbourne Law School, commenced activities in 1985 and is the first and largest centre devoted to the development of our understanding of Asian law and legal systems. The Centre has pioneered extensive programs of teaching and research on the laws and legal systems of Japan, China, Indonesia, Vietnam, Taiwan, Malaysia, Islamic law, East Timor and the Philippines.

The Director of the Centre is Professor Pip Nicholson and the Centre Manager is Kathryn Taylor. The Centre website can be accessed at www.law.unimelb.edu.au/alc

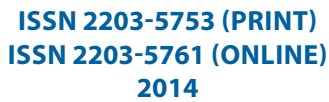

\section{COPYRIGHT}

All information included in the CILIS Policy Papers and ALC Briefing Papers is subject to copyright. Please obtain permission from the original author(s), the Centre for Indonesian Law, Islam and Society (lawcilis@unimelb.edu.au) or the Asian Law Centre (law-alc@unimelb.edu.au) before citing from the Policy Papers. The Policy Papers are provided for information purposes only. The Centre for Indonesian Law, Islam and Society and the Asian Law Centre do not guarantee the accuracy of the information contained in these papers and do not endorse any views expressed or services offered therein.

Front Cover Image: Image by Tessa Shaw. 


\title{
Clemency in Southeast Asian \\ Death Penalty Cases
}

\begin{abstract}
The five contemporary practitioners of the death penalty in Southeast Asia (Indonesia, Malaysia, Thailand, Singapore and Vietnam) have performed judicial executions on a regular basis between 1975 and 2013. Notwithstanding this similarity, the number of death sentences passed by courts that were subsequently reduced to a term of imprisonment through grants of clemency by the executive has varied remarkably between these jurisdictions. Some of these countries commuted the sentences of death row prisoners often (for example, the clemency 'rate' of 91-92 per cent witnessed in Thailand), others rarely (a clemency 'rate' of around 1 per cent in Singapore), and some at 'medium' rates. In this article, I employ the methodology of comparative criminal justice to explore the discrepancies and similarities in capital clemency practice between these five Southeast Asian jurisdictions. In doing so, I seek to identify the structural and cultural reasons why retentionist countries exercise clemency at vastly different 'rates' in finalised capital cases.
\end{abstract}

\section{Dr Daniel Pascoe}

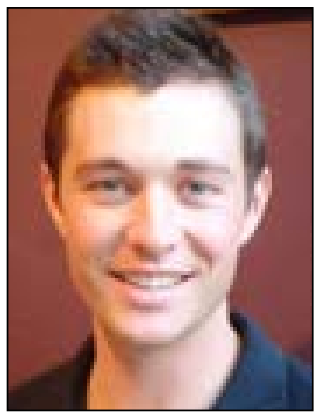

Daniel Pascoe completed his Doctor of Philosophy in Law at the University of Oxford in October 2013, after previous degrees in Law, Asian Studies (Indonesian) and Criminology/Criminal Justice. He is currently an Assistant Professor at the School of Law, City University of Hong Kong, where he teaches in the Juris Doctor programme. 


\title{
Clemency in Southeast Asian Death Penalty Cases
}

\author{
Dr Daniel Pascoe
}

All five contemporary state practitioners of the death penalty in Southeast Asia Indonesia, Malaysia, Thailand, Singapore and Vietnam - have executed prisoners sentenced to death on a regular basis over the past few decades. ${ }^{1}$ Nonetheless, there is remarkable variance in the proportion of death sentences imposed by the courts of these neighbouring countries that are later reduced to a term of imprisonment, or end with the prisoner being released from custody altogether, as a result of grants by the executive branch of government of clemency or pardon. ${ }^{2}$

This paper is based on the findings of my doctoral dissertation, prepared at the University of Oxford between 2010 and 2013. In it, I analyse differences in clemency practice among the Southeast Asian jurisdictions that continue to apply the death penalty, in an inductive and comparative ${ }^{3}$ search for plausible hypotheses explaining why some countries have made use of clemency more often than others since the end of the Vietnam War and the beginning of the regional anti-drug 'paradigm' in $1975 .{ }^{4}$ This was the year when the death penalty became a criminal punishment for drug trafficking in Singapore (mandatory); Malaysia (discretionary, mandatory from 1983) and Indonesia (discretionary). Thailand and Vietnam followed suit with discretionary death penalties for drug offences in 1979 and 1992, respectively.

Although extrapolating the findings of a study of only five retentionist jurisdictions

1 Amnesty International, 1997: 1; and Amnesty International, 2011a: 45. The statistics I relied upon in compiling this report are held on file.

2 For present purposes, 'clemency' refers to the substitution of a sentence of death with a lesser punishment, usually a term of imprisonment. See Palmer, 2001: 110; and Coyne and Entzeroth, 2001: 838. I will include 'pardons' (where the prisoner is granted an unconditional release from prison) within this broader definition, as pardons in death penalty cases are exceedingly rare. See Scott, 1952: 96; and Burnett, 2002: 14.

3 See Lijphart, 1971: 687; Kohli et al, 1995: 17; Neuman, 2005: 60, 76-77; Johnson and Zimring, 2009: 38; and Nelken, 2011: 395-396 for more details of this kind of research methodology and its academic justifications.

4 During the past few decades, Southeast Asia has been the only region where the majority of death sentences issued and executions carried out have been for drug offences. See Amnesty International, 2007; Johnson and Zimring, 2009: 309; and Human Rights Watch, 2009. 
to other parts of the world must be undertaken with caution, this research has the potential to add to what are scarce bodies of literature on clemency and pardons in capital cases (globally) and the death penalty in Southeast Asia (locally). It may also assist the formulation of theories and hypotheses that could be tested in future studies of the death penalty.

\section{RESULTS OF THE STUDY}

\section{Low, medium and high - the statistical findings on clemency}

Despite all five jurisdictions conducting executions on a reasonably regular basis since 1975 , the percentage of death sentences where the prisoner has exhausted available judicial remedies and is then granted clemency rather than being executed (what I label the clemency 'rate'), differs greatly across national borders.

In retentionist Southeast Asia there is one country with an extremely low clemency rate of approximately 1 per cent (Singapore). There are three countries where clemency, while not an exceptional measure, is nonetheless not the expected alternative to execution in a capital case, with 'rates' of 26-40 per cent (Malaysia), 24-33 per cent (Indonesia), and 6-23 per cent (Vietnam). Finally, in Thailand, clemency is the form of legal relief that a prisoner who has exhausted judicial appeals can expect in the majority of cases (91-92 per cent)..$^{5}$ Actively retentionist Southeast Asia therefore provides examples of what I label 'low', 'medium' and 'high' rates of clemency.

Calculating these figures does present significant methodological challenges, the most notable being a potentially large number of unreported clemency grants and executions, together with data unavailable for years that do not correspond across the five different jurisdictions. Nevertheless, identifying a set of statistical estimates - a process that has never been attempted with any precision in Southeast Asian jurisdictions - offers data that can be built on in future studies of capital punishment in the region.

How have I determined the percentile ranges 'low', 'medium' or 'high' as they apply to clemency rates here? While these are relative terms, it is instructive that in the United States (the country on which most of the theoretical work on the death penalty has been based) clemency 'rates' peaked in the mid-20 th century at just over 40 per cent. Since the reinstatement of capital punishment in 1976, they have fallen to around 18 per cent. In the United Kingdom, between 1900 and the abolition of the death penalty in 1965, the proportion of cases in which clemency was granted was similar: around 35-40 per cent. The same proportions are evident in former British colonies with common law legal systems when they applied the death penalty. I have taken the US-UK figures as a median point of reference, and therefore placed those countries within the 'medium' clemency band.

See note 1 , above, on statistics. 
If we assume that clemency would, in a majority of contemporary retentionist jurisdictions, be denied more often than it is granted (given that the grant of clemency 'overturns' the prior sentencing judgment of the courts), then 50 per cent appears an appropriate lower marker for the 'high' clemency threshold.

As for the 'low' clemency threshold, I intend that the band should indicate circumstances in which clemency, while technically a legal right for condemned prisoners, is nonetheless hardly ever exercised. As the Anti-Death Penalty Asia Network (ADPAN) noted in a 2011 report on capital punishment in the Asia-Pacific region, 'In several countries in the region, clemency procedures are either absent or exist only on paper' (Amnesty International, 2011b: 32). Whether that threshold is placed at one per cent, or anywhere up to five per cent, it would still include Singapore, by far the most frugal of the five jurisdictions studied when it comes to clemency.

\section{Factors contributing to clemency 'rates'}

After meticulous collection of statistical and qualitative case-based data on clemency through archival research in the UK, Australia and four of the five jurisdictions under study, ${ }^{6}$ together with internet-based sources, the primary interpretive challenge has been to explain each country's position on this broad 'spectrum' of clemency use.

Having completed the data-collection process, and analysed the clemency grants identified within the context of the relevant theoretical literature on clemency and pardons in death penalty cases, my preliminary conclusions are that in modern retentionist Southeast Asia, the proportion of finalised cases in which clemency is granted is significantly influenced by three key legal and political attributes of each jurisdiction, reflecting the three common functions that clemency appears to perform in Southeast Asian nations:

1. The amount of lenient discretion exercised at earlier stages within the criminal justice system;

2. The extent to which granting clemency enhances or detracts from political power (which is closely related to the type of government granting clemency); and

3. The usual length of time capital prisoners spend incarcerated before execution.

6 I visited Singapore, Kuala Lumpur, Bangkok and Jakarta to undertake field research between 2011 and 2013. I did not visit Vietnam, as death penalty information there has been a state secret since 2004. I relied upon sources written in English, Indonesian and Malay but could not use Thai language sources, hence interviews conducted in English and through interpreters in Bangkok played a larger role there. I have anonymised the identities of all interview subjects and hold the transcripts of the interviews on file. 
I now discuss each of these factors in turn.

1. CLEMENCY AND LENIENT DISCRETION

My interpretation of the Southeast Asian cases indicates that clemency is granted in a significant proportion of finalised cases where the relevant criminal justice system lacks other mechanisms to individualise punishments, or to keep the annual number of executions to a politically manageable level. Of the five countries under analysis, pertinent examples here include the military 'show' trials of alleged PKI (Partai Komunis Indonesia, Indonesian Communist Party) prisoners during the early Soeharto period in Indonesia (Amnesty International, 1988: 2), and the regular processing of death penalty cases through Thailand's and Vietnam's criminal justice systems.

In the former case, the story of publicly reported clemency grants in Indonesia from 1975 largely involves the subversion trials of accused PKI members and associates following the failed coup of 1965 . Those convicted were not accorded any right to appeal death sentences imposed by the Mahmillub (Mahkamah Militer Luar Biasa, Extraordinary Military Tribunal) set up after the coup attempt, other than to appeal to the President for clemency. ${ }^{7}$ Moreover, convictions upon charges being laid were universal: not one prisoner was ever acquitted in either military or civil trials relating to the coup attempt, although it appears some death sentences were at least reduced on appeal in the civil courts. ${ }^{8}$

In Thailand, clemency as a form of lenient discretion is prompted by the very large number of death sentences imposed at first instance (175 is the highest 1980s figure for a single year, 109 in the 1990s, and 447 in the 2000s), and Thailand's status as one of the 'world capital[s] of overcharging'. ${ }^{9}$ It is also a result of the fact that, despite two levels of judicial appeals, the number of prisoners remaining on death row at the conclusion of the judicial process is by far the largest of any of the five jurisdictions under study. ${ }^{10}$ While some level of lenient discretion is undoubtedly exercised by Thai police, prosecutors and judges where mitigating circumstances attach to the defendant and his or her case, and while corruption is also present, these factors are not enough to reduce the numbers of executions to a symbolic and manageable level, given that

7 Article 7(2), Presidential Decree No 16 of 1963 on the Extraordinary Military Tribunal (Indonesia).

8 Amnesty International, 1984: 1; Amnesty International, 1985b: 2; Lev, 1999: 187; and Lev, 2011: 233.

9 That is, charging accused persons with large numbers of serious offences. (Interview with American Academic Expert on Capital Punishment (Hong Kong, 7 November 2011)).

1065 being the highest finalised death row population in the 1980 s, 70 in the 1990 s, and 127 in the 2000s. 
capital punishment's main purpose is to highlight the state's lack of tolerance for a particular form of crime and to make an example of the offender. ${ }^{11}$ Grants of Individual and Collective Royal Pardon authorised by King Bhumibol Adulyadej since his ascent to the throne in 1946 operate here to fill the breach (as well as for other purposes, discussed later in this paper).

In Vietnam, examples where judges have exercised lenient discretion to reduce sentences to something less than death or to acquit the defendant outright are rare. It is likely that largely determinative 'pre-trial conferences' in capital cases, ${ }^{12}$ a 95 per cent conviction rate at trial, and the 99.93 per cent appeal rejection rate ${ }^{13}$ have all directly contributed to the medium clemency 'rate' of the late 1990s and the 2000s. Significantly, testing the evidence against the defendant or considering mitigating circumstances are not matters for the courtroom in Vietnam, ${ }^{14}$ with the defence lawyer's primary role being to advocate for clemency on a capital defendant's behalf. ${ }^{15}$

The converse situation arises, that is, clemency is not granted with any significant frequency, where there are substantial mechanisms for the exercise of lenient discretion at earlier stages of the criminal justice system. Such discretion may consist of a decision by police and prosecutors to reduce charges or to discontinue prosecution altogether; or may consist of acquittal and sentencing discretion at the first-instance trial, appeal and ultimate appeal stages. In Indonesia, it may also apply to the further 'extraordinary' legal mechanism of case review (peninjauan kembali, PK). ${ }^{16}$ Discretion is exercised through these various channels for three main reasons in capital cases: to consider mitigating factors associated with an individual prisoner or with the facts of the case and the legal proceedings surrounding it; to keep execution numbers down to domestically and/or internationally tolerable levels; and, particularly in the case of Indonesia, because corruption within the legal system reduces the sentence or absolves the defendant completely.

In the present study, examples of jurisdictions where the death penalty system operates

11 Interview with Australian Academic Expert on Thailand (Canberra, 16 September 2009); interview with Singaporean Criminal defence lawyer (Singapore, 10 October 2011); and interview with Thai Human Rights activist (Bangkok, 7 September 2012).

12 Nicholson and Truong, 2008: 436; and Johnson and Zimring, 2009: 390.

13 Nicholson and Truong, 2008: 442; and Hands Off Cain, 2013c.

14 Nicholson and Truong, 2008: 455-456.

15 Amnesty International, 1997: 22; and AI-Index ASA 41/023/2003, 3.

16 See art 263(2) of Law No 8 of 1981 on Criminal Procedure (Indonesia); and art 67 of Law No 14 of 1985 on the Supreme Court (Indonesia). 
in such a fashion are Singapore (prosecutorial discretion); Malaysia (both judicial and prosecutorial discretion); and Indonesia (judicial and prosecutorial discretion, with the exception of the PKI cases, referred to above). Here, the practical effect of discretion exercised at earlier stages is that by the time the case reaches the head of state or other government decision-maker for clemency, all relevant mitigating factors have already been considered. Accordingly, very few case-related arguments remain to stop the execution proceeding. The fact that relevant mitigating factors have already been considered is often communicated in a practical sense by the constitutional and legislative provisions mandating that advice to the final decision-maker on clemency is provided by the Attorney-General (public prosecutor) in Singapore and Malaysia, ${ }^{17}$ and regional and national prosecutors in Indonesia, together with the Supreme Court's criminal chambers. ${ }^{18}$

2.

\section{CLEMENCY AND POLITICAL POWER}

Within this second conception of clemency, the power to spare a condemned prisoner's life is frequently used - or sidelined - in circumstances where it has a substantial positive or adverse effect on the political power, prestige or popularity of the head of state or other relevant clemency decision-maker. Based on the data collected from the five jurisdictions, clemency is granted in significant numbers where the figure publicly perceived as bearing the political responsibility for the decision to grant clemency or pardon is not elected by popular vote. Here, clemency is used in conjunction with capital punishment as a strategy to be seen to rule by benevolence, or as a demonstration of power over life and death, so as to gain authority over domestic constituents by state terror and fear. ${ }^{19}$ Likewise, the selective or wholesale granting of clemency to foreign nationals (or to locals in response to significant foreign pressure) is a means of gaining greater international legitimacy, notwithstanding a government's authoritarian characteristics in the domestic setting. ${ }^{20}$

The most pertinent examples within Southeast Asia are the long-established and religiously-influenced traditions relating to the exercise of the power to pardon by Thailand's King Bhumibol and Malaysia's nine Islamic Hereditary Rulers, all of whom

17 Constitution of Singapore 1965, art 22P(2); Talib, 1989: 64; and Lee, 2006: 472.

18 Article 14(2) of the Constitution of Indonesia 1945; art 8 of Law No 3 of 1950 on Clemency (Indonesia); Amnesty International, 1985a; arts 4(1), 10, 11 of Law No 22 of 2002 on Clemency (Indonesia); Elda, 2009: 89; and interview with Australian Academic Expert on Indonesia (Telephone interview, 30 January 2013).

19 For theoretical background see Strange, 1996: 7; and Botsman, 2007: 49. This was confirmed in my interview with American Academic Expert on Capital Punishment (Hong Kong, 7 November 2011).

20 See Neumayer, 2008: 242; and Johnson and Zimring, 2009: 318, 334. 
receive multiple recommendations on each clemency petition as part of the scheme of constitutional monarchy, yet retain the absolute discretion to grant or withhold pardon as they see fit (and do sometimes exercise this discretion). ${ }^{21}$ The exercise of royal prerogative in these cases concurrently achieves the goals of portraying the traditional ruler as religiously pious (especially for the Thai king's actions, typically seen as reflecting the Buddhist Law of Kingship, or Dhamma);22 as taking a close interest in the welfare of his constituents; and as maintaining good relations with abolitionist nations. It generally helps maintain the relevance and popularity of the monarchy as an institution within a constitutional scheme where elected politicians alone determine state policy (and, in the case of Malaysia's Hereditary Rulers, have actively sought to restrict the independent exercise of royal prerogative powers). ${ }^{23}$

Indonesia during the period of President Soeharto's autocratic rule also appears to fit this paradigm, with clemency for the accused PKI prisoners in the early 1980s being granted with the primary aim of easing international pressure on the regime, following foreign criticism over widespread human rights abuses. ${ }^{24}$ President Habibie's revocation of death and prison sentences imposed on numerous political prisoners in 1998 and 1999 followed similar reasoning, and was also a response to a need to maintain domestic support for steps taken towards democratisation. ${ }^{25}$ For these two Indonesian leaders, neither of whom attained power through free elections, clemency grants awarded to political prisoners added to their international and domestic legitimacy.

Likewise, in contemporary Vietnam, the unelected and authoritarian socialist government has taken a number of liberalising steps in relation to its death penalty laws and practices in recent years. Examples of reforms seemingly made in order to portray a more 'human' face to the outside world include:

- the two-stage reduction of death-eligible crimes from 44 in 1999 to 21 since

21 The Nation, 2001; interview with Thai Law Professor (Bangkok, 14 September 2012); interview with Thailand's Department of Corrections Staff (Bangkok, 24 September 2012); Addruse, 1986: 2; Talib, 1989: 39; and Faruqi, 2008.

22 See Chotibal, 1990; Anand, 1996: 2; Handley, 2006: 434; and van Oosten, 2008: 258.

23 See Richardson, 1992; Constitution (Amendment) Act 1994 (Malaysia); and Kershaw, 2001: 160.

24 TAPOL, 1995: 2; interview with London-based Indonesian Human Rights activist (London, 22 August 2011); and interview with senior Indonesian Human Rights lawyer (Jakarta, 11 April 2013).

25 Antara, 1999; interview with senior Indonesian Human Rights lawyer (Jakarta, 11 April 2013). 


\section{$2010 ; 26$}

- abstention at the UN General Assembly's vote on a death penalty moratorium from 2007 to 2012 ;

- banning executions for young mothers and juveniles; ${ }^{27}$ and, most significantly here

- the granting of clemency to nearly all Western prisoners sentenced to death, together with a number of different prisoners from Asian nations (although a few Asian prisoners have been executed since the mid-1990s). ${ }^{28}$

An influential practical feature of clemency granted to enhance political power and prestige is that, regardless of the relative merits of each individual prisoner, such grants are often awarded in aggregate form. Relevant examples include the regular issuing of Collective Royal Pardons in Thailand (which sometimes empties death row entirely); Soeharto's and Habibie's pardons of Indonesian political prisoners en-masse; the Vietnamese State President announcing several clemency grants (but also several rejections) simultaneously; and, finally, the results of Malaysian Pardons Board meetings (although the explanation in this jurisdiction may be more to do with the long intervals between sittings, rather than a desire to maximise the political impact of clemency by making multiple grants). Importantly, given the infrequency with which clemency and pardons are normally granted in most retentionist jurisdictions, any grants made on a collective basis will often skew the available statistics, dominating accumulated clemency totals (in this case, since 1975), and therefore having a significant and disproportionate influence on the historical clemency 'rate'. ${ }^{29}$

Conversely, the results of this study suggest that clemency does not exist on a widespread

26 Hands off Cain, 2013c.

27 Babcock, 2013. The death penalty was first banned for 14-15 year old offenders, and subsequently for 16-17 year olds, pursuant to art 74(1) of the Penal Code 1999.

28 See note 33, below.

29 Note here the compelling example of Illinois Governor George Ryan, whose emptying of his state's entire death row in 2003 had a major impact on historical death penalty clemency rates across the United States. Between 1977 and 2008 there were 1136 executions carried out in the United States, and 244 prisoners granted clemency for humanitarian reasons (that is, excluding clemency granted only in order to avoid a re-trial or for other procedural reasons, see Acker, 2010: 186), resulting in a clemency 'rate' of approximately 18 per cent. However, if the 167 death sentences commuted by Governor George Ryan in his single 2003 executive decree are removed from these statistics, the national clemency percentage drops to approximately seven per cent. See Death Penalty Information Center, 2013. 
basis where a popularly elected clemency decision-maker's criminal justice policy extends to the promotion of the rule of law or the strengthening of legal enforcement efforts. Here, granting clemency (at least where reported publicly) constitutes a significant political liability, rather than being of political benefit (as was the case for autocratic regimes). Relevant examples within the present study are the People's Action Party Cabinet in Singapore (during the entire period of study); the Mahathir-led government in Malaysia during the period 1983 to $1994 ;{ }^{30}$ and the administrations of Indonesia's three Reformasi-era presidents from October 1999 onwards: Abdurrahman Wahid, Megawati Sukarnoputri and Susilo Bambang Yudhoyono.

Clemency has been reduced to extremely low levels in these three jurisdictions where the elected political leaders (who are also the clemency decision-makers), have considered it valuable to give priority to the 'rule of law' in the criminal justice system, and to treat cases as impartially as possible, with the courts alone ruling on alleged unfair applications of the law. In practical terms, this has meant (at least at the clemency phase) a purportedly 'even-handed' upholding of the death sentence for women and men, the rich and poor, the very young and very old, and foreign nationals as against locals. ${ }^{31}$ Moreover, when clemency petitions are considered, they are considered strictly on an individual basis, unlike the collective grants described above.

One of the most visible and controversial effects of this emphasis on 'rule of law', and of uncompromising deterrence in drug cases, comes in relation to foreign nationals on death row. Within the jurisdictions where 'rule of law' rhetoric has been stringently applied in relation to criminal justice, and particularly in drug trafficking cases (Singapore since 1975, Malaysia from 1983 to 1994, Indonesia since 1999), it is significant that clemency has not been awarded in a single known case of a foreign national facing death following international pressure. ${ }^{32}$

30 Although the Malay Hereditary Rulers, Governors, and the Malaysian King (Yang diPertuan Agong) have the final say on clemency in Malaysia, the UMNO-led government is able to make strong recommendations to sway these ultimate decision-makers through the presence on the Pardons Boards of the Federal Attorney-General (or his delegate), the local Chief Minister and perhaps even politically sympathetic lay members (see art 42 of the Constitution of Malaysia 1963).

31 However, intervention by prosecutors, which is far less visible publicly, is a separate issue, and is discussed below.

32 A major exception to this occurred in October 2012, when it was announced that Indonesian President Yudhoyono had granted clemency to four drug traffickers sentenced to death during his term in office, a group that included a Nepalese national (Kontras, 2010; and Saragih, 2012). The second possible exception here may have been the clemency grants accorded to a number of Indonesian migrant workers sentenced to death in Malaysia in the 1990s, although the various sources suggesting the existence of these grants do not provide specific names or dates (see Amnesty International, 1997: 13; Perry, 2009; Osman, 2010; and Riza and Kurniawan, 2010). The fact remains, however, that no Westerner has 
Preferential treatment at the investigatory or prosecutorial phase is a different matter entirely, as the exercise of lenient discretion by police or prosecutors is not nearly as publicly visible and therefore does not compromise the political imperative to be seen as administering capital punishment in an even-handed manner. In contrast, in known cases in Vietnam since the mid-1990s, ${ }^{33}$ in Thailand since 1975, and in Malaysia from 1975 to 1982, and again since 1995, the clemency appeals of numerous foreign nationals (particularly those receiving backing from the highest levels of their own governments) have been approved. In Indonesia's case, it is unclear how many capital clemency requests relating to foreign nationals ever reached President Soeharto for consideration, but there is conclusive evidence that only one foreign national (a Malaysian) was executed during the entire period 1975 to $1999,{ }^{34}$ compared with seven (non-Western) foreign nationals during the Reformasi period, the latest in November 2013. ${ }^{35}$

3.

CLEMENCY AND TIME SPENT ON DEATH ROW

The third and final conception of clemency that the Southeast Asian data appear to support is clemency as a response to excessive time spent on death row. Based on my observations of death penalty practice in Malaysia, Thailand, Soeharto-era Indonesia and possibly also Reformasi-era Indonesia, clemency can be granted in significant proportions if loopholes in the precise legal procedures for clemency operate to frustrate the executive government's desire to increase the processing pace, and volume of, executions.

Within these three jurisdictions, the languid pace of investigations, trials, judicial appeals and clemency proceedings can often exceed 10 years, and sometimes more than 20 years. When the length of time an offender spends in prison on remand while judicial appeals are on foot and on death row begins to be measured in decades rather

ever had his or her death sentence commuted within those jurisdictions during the periods mentioned above.

33 Only one Western citizen has been executed in Vietnam since 1975, a Vietnamese-Canadian woman, Nguyen Thi Hiep, in 2000, for trafficking five kilograms of heroin, (McGregor, 2004; and Asia Death Penalty Blog, 2008). In contrast, various Asian prisoners have been executed in Vietnam since 1995, however Cambodian, Laotian and Thai prisoners have also had their sentences commuted at the same time that other Vietnamese prisoners had their clemency petitions rejected (Agence France Presse, 1997; and Hands Off Cain, 2013c). In these cases, it appears that diplomatic appeals from foreign governments and multinational corporations operating in Vietnam, or the prisoner providing evidence to break up a drug-trafficking network and secure the conviction of accomplices, were the relevant factors taken into account by the Vietnamese leadership.

34 Imparsial, 2010: 119-131; and Kontras, 2010.

35 Imparsial, 2010: 167; Human Rights Watch, 2013; and Cristianson, 2013. 
than in years, it becomes less likely that an executive decision-maker will authorise an execution, and execution in these circumstances can even come to be perceived as unconscionable.

The one exception here has been the case of Soeharto-era Indonesia, where the executions of accused PKI coup-plotters and associates were halted in the late 1960s due to pressure from foreign governments and NGOs, only to be resumed in 1985, with the justification that it would demonstrate to the Indonesian public the latent danger of communism. ${ }^{36}$ Additionally, in a number of murder and Islamic subversion cases during Soeharto's rule there were executions conducted around 15 years after the firstinstance death sentence was pronounced. ${ }^{37}$

However, in other Indonesian cases and in cases in neighbouring jurisdictions, death sentences have been commuted to a term of imprisonment, or prisoners released outright after serving their 'punishment' on death row for a long period. These commutations have been achieved through established official procedures such as Malaysia's Pardons Boards or Thailand's system of Individual Royal Pardons, in addition to the unofficial remissions procedure that several commentators have identified as existing during New Order Indonesia (and perhaps also during the Reformasi era). ${ }^{38}$ While it is unclear on the face of it whether the length of time spent on death row can be considered a causative factor for clemency, or a factor caused by general political ambivalence over the death penalty (which could also lead to frequent grants of clemency), clues may be found in the reasons why prisoners have spent as long as 20-30 years with an indeterminate fate. In many cases, the causes are procedural (or, at worst, highly negligent), rather than political and deliberate.

Various legal and political mechanisms have frustrated the desire to carry out executions more quickly in each of the three relevant jurisdictions. In Malaysia, the slow pace of judicial appeals, together with infrequent sittings of the Pardons Boards in a number of states, have left prisoners waiting for a response to their appeals for between 10 and 25 years. In Thailand, the slow judicial appeal process, combined with the bureaucratic clemency appeal process for Individual Royal Pardons (exacerbated by the ill health of King Bhumibol in the 2000s), have resulted in long and indeterminate stays in detention for many prisoners. This is particularly true for those barred from consideration for Collective Royal Pardon because of their behaviour in prison, or because they were sentenced for a crime perceived as particularly serious at the time and thus excluded from the scope of such pardons. In both Malaysia and Thailand there is evidence

36 TAPOL, 1980: 2-3; and Murray, 1991: 19.

37 Amnesty International, 1988: 3; Glasius, 1999: 93; Bampton, 2006: 7; and Afrida, 2012.

38 Amnesty International, 1987a; Amnesty International, 1987b; and Amnesty International, 1988: 3,5 . 
to suggest that prisoners have been granted clemency on an individual basis after relevant executive decision-makers considered their one or two decades spent on death row sufficient 'punishment' for their crime.

In Indonesia, loopholes in the 1950 and 2002 Clemency Laws allowed indefinite time for the preparation of a clemency petition (in the former Law) and likewise for a second petition (in the latter Law). ${ }^{39}$ Significantly, a number of the PKI prisoners, like defendants in unspecified murder cases, have used these provisions to delay execution for as long as possible, rather than risk having their ultimate clemency appeal rejected. The decades these prisoners spent on death row, and the decline in political importance of their cases over time, were most likely considered through an unofficial prisons remission policy. This was true also in the case of President Habibie's release of political prisoners during 1998 and 1999.

Practically, the longer that procedural complications extend a prisoner's stay on death row, the greater the opportunity for the prisoner to demonstrate attributes making him or her worthy of commutation of sentence and eventual release. Demonstrated rehabilitation, religious piety and remorse may be the most obvious examples, yet less visible factors, such as assistance with ongoing police investigations, psychiatric or terminal illness, old age, family illness, the outright bribery of officials, and (as we saw in the Indonesian example) an eventual change to a more liberal regime ${ }^{40}$ are also factors created by the passing of time that can greatly improve a prisoner's chances of clemency.

In Singapore, however, the available data point to precisely the opposite conclusion, and in Vietnam the authorities have never publicly justified grants of clemency on the basis of time spent on death row. In Singapore, the maximal efficiency of the death penalty machinery ${ }^{41}$ means clemency petitions have generally only been considered by the Cabinet on the basis of retributive principles. Historically, the time required for the advent of time-based mitigatory concerns has simply not existed before execution. Incountry interview sources generally suggested that the total time a prisoner spends in detention in Singapore - from arrest through to execution - seldom exceeds two years. ${ }^{42}$ In Vietnam, a 2003 Amnesty International report suggested the range of time spent

39 See Law No 3 of 1950 on Clemency (Indonesia); and Law No 22 of 2002 on Clemency (Indonesia).

40 See generally The Jakarta Post, 1998; and Schabas, 2004: 1086-87.

41 Hor, 2004: 115; and Johnson, 2013: 43.

42 Ravi, 2005: 78; Anandan, 2009: 162; interview with Singaporean Criminal defence lawyer (Singapore, 10 October 2011); Johnson, 2013: 43; and Hands Off Cain, 2013b. 
incarcerated before execution is between five months and four years. ${ }^{43}$ Accordingly, my assumption is that the length of time spent in prison before either execution or clemency is the third major contributing factor explaining Southeast Asian clemency 'rates'.

\section{FITTING THE THREE FACTORS TOGETHER}

In future academic studies, it may be possible to test these hypotheses on a quantitative basis, however, it is possible to conduct a preliminary assessment of the model without engaging in a regression analysis. This can be done by means of a matrix of explanatory factors, similar to the 'method of difference' favoured by certain scholars in the comparative historical methods field. ${ }^{44}$

Considering the three potential explanatory factors together, it is apparent that the country whose criminal justice and political system supports clemency grants in none of these three forms (Singapore) has an extremely low overall clemency 'rate'. Conversely, the country where clemency performs all three functions, Thailand, has an extremely high clemency 'rate'. Finally, the three countries with 'medium' clemency rates over their modern history all demonstrate mixed results on the same tripartite test, although 'scoring' the three factors for Indonesia and Malaysia is more difficult, given significant policy changes over the period 1975 to 2009, and the unavailability of some relevant data in both cases. ${ }^{45}$ Likewise, Vietnam's statistics can only be compiled from the period 1997-2008, a more narrow timeframe than the other four jurisdictions, where partial statistics at least are available back as far as 1975 .

44 See, for example, Skocpol and Somers, 2006: 206-207; and Anckar, 2007: 54. 


\begin{tabular}{|l|c|c|c|c|c|}
\hline $\begin{array}{l}\text { Clemency } \\
\text { Function }\end{array}$ & Singapore & Thailand & Malaysia & Indonesia & Vietnam \\
\hline $\begin{array}{l}\text { Lenient } \\
\text { Discretion }\end{array}$ & $\mathrm{X}$ & $\checkmark$ & $\mathrm{X}$ & $\checkmark$ and $\mathrm{X}^{*}$ & $\checkmark$ \\
\hline $\begin{array}{l}\text { Political } \\
\text { Power }\end{array}$ & $\mathrm{X}$ & $\checkmark$ & $\checkmark \quad \begin{array}{c}\text { and } \\
\mathrm{X}^{* *}\end{array}$ & $\begin{array}{c}\checkmark \text { and } \\
\mathrm{X}^{\star * *}\end{array}$ & \\
\hline $\begin{array}{l}\text { Time on } \\
\text { Death Row }\end{array}$ & $\mathrm{X}$ & $\checkmark$ & $\checkmark$ & $?^{* * * *}$ & $\mathrm{X}$ \\
\hline $\begin{array}{l}\text { Clemency } \\
\text { 'Rate' } \\
\text { Indication }\end{array}$ & Rare & Common & Mixed & Mixed & Mixed \\
\hline $\begin{array}{l}\text { Observed } \\
\text { Clemency } \\
\text { 'Rate' }\end{array}$ & $\begin{array}{c}\text { Low } \\
(1 \%)\end{array}$ & $\begin{array}{c}\text { High } \\
(91-92 \%)\end{array}$ & $\begin{array}{c}\text { Medium } \\
(26-40 \%)\end{array}$ & $\begin{array}{c}\text { Medium } \\
(24-33 \%)\end{array}$ & $\begin{array}{c}\text { Medium } \\
(6-23 \%)\end{array}$ \\
\hline
\end{tabular}

* Clemency performed the role of lenient discretion following the PKI trials but not in other cases, either under Soeharto or during the Reformasi period.

** Note the 1983-1994 conflict between the 'no mercy' policy for drug trafficking and the continued exercise of royal prerogative by the Hereditary Rulers and Yang di-Pertuan Agong.

*** Clemency was granted to enhance political power under Soeharto, whereas the Reformasi Presidents have preferred a more even-handed dispensing of justice at the clemency phase.

**** This practice was likely during the Soeharto period, and entirely possible within the post-Soeharto period as part of an unofficial prisons 'remission' policy. The true incidence of 'unreported' clemency grants in Indonesia may never be known.

This model is far from perfect, and suffers the significant data shortcomings described earlier. Moreover, it is unclear whether or not equal or different weight should be given to each of the three potential explanatory factors in determining the final clemency 'rate'. However, bearing in mind these caveats, my three-factor model does a serviceable job of explaining the relative incidence of clemency, according to theoretically-relevant explanations, at least for the five Southeast Asian jurisdictions selected.

I observed earlier that care must be taken in attempting to automatically extrapolate the findings of this study to other parts of the retentionist world, assuming that the three explanatory findings have the potential to inform a 'global' theory of clemency rates. In time, quantitative testing may achieve this result. However, what my study has achieved is to shed light on a previously understudied phenomenon (clemency) in an understudied region of the world (Southeast Asia), at least so far as criminal justice is concerned. In the broader context of capital punishment studies, the data contained 
in this study also go a small way to rectifying the dearth of academic studies on the operational similarities and differences of death penalty practice within retentionist jurisdictions (as opposed to studies contrasting retentionist with abolitionist states). Moreover, such evidence-based findings suggest key lessons for capital defence lawyers and policy makers, which I will now describe.

\section{POLICY IMPLICATIONS OF THE MODEL: SEEKING CLEMENCY FOR CAPITAL DEFENDANTS IN SOUTHEAST ASIA}

Based on the three general explanations for clemency frequency in Southeast Asia outlined in this paper, three policy implications arise for capital defence lawyers, diplomatic staff and government policy-makers working in the area. Importantly, these recommendations are distinct from (and sometimes contradictory to) the campaigning strategies often employed to further the cause of outright constitutional or legislative abolition of the death penalty. The strategies I propose are instead part of an evidencebased response to the plight of current defendants facing the death penalty in Southeast Asia (and potentially elsewhere in the retentionist world).

\section{Clemency as lenient discretion}

I observed above that lenient discretion has been exercised at various points in retentionist criminal justice systems. This sometimes occurs earlier in the processing of a criminal case (that is, by police or prosecutors) and sometimes later, in the form of outright acquittals or sentence reductions on appeal (at the judicial phase). It can also be executed by the executive (at the clemency phase). Inverting this idea, we see that even in jurisdictions where comparatively little lenient discretion is exercised at the clemency phase (notably Singapore and democratic-era (1999-2013) Indonesia, which have clemency 'rates' of one per cent and 15-16 per cent, respectively), leniency for capital prisoners is still commonly shown by the authorities at earlier, and perhaps less visible, phases of the process. Accordingly, there are opportunities to avoid a death sentence by adopting appropriate strategies at earlier phases.

In Southeast Asia it is notable that high-profile legal counsel are often only sought or appointed as a case proceeds towards execution, and likewise diplomatic representations are often only made with any real force during the clemency phase. The results of my study suggest, first, that a more effective strategy would involve the appointment of effective counsel at the earliest possible phase (that is, after consular notification of arrest). Second, notwithstanding the diplomatic protocol against interference in the justice system of another sovereign nation, representations for leniency made by foreign governments (and also by defence lawyers) are also likely to be far more effective when carried out before charges are laid by prosecutors. Third, defendants facing the death penalty abroad, and their families, should be aware that bribery of public officials (where this is attempted as a means of escaping the death sentence despite the obvious serious ethical and legal issues it raises) will be more effective if attempted before the case reaches trial. 
Pertinent examples of discretion exercised at earlier phases consist of Singapore's '14.99' drug charges and findings of culpable homicide instead of murder; ${ }^{46}$ Malaysia's recent acquittal rate of 50-60 per cent in capital drug cases; ${ }^{47}$ and Indonesia's high level of corruption at the investigatory and prosecutorial phase. ${ }^{48}$ Naturally, in these countries the most effective defence strategy is not to let a death sentence reach the clemency phase in the first place. Given that prosecutors and judges have significant legal and constitutional roles in providing advice to final clemency decision-makers in Singapore, Malaysia and Indonesia, ${ }^{49}$ it is far better to intervene and fight the case before charges are confirmed or an initial conviction is recorded.

\section{Clemency as political power}

Here, the results of my study suggest that diplomatic representations, calling for clemency on the grounds of maintaining good bilateral relations with an abolitionist country, are most effective when (a) they involve support from the highest levels of the foreign prisoner's government; and (b) are directed at authoritarian or unelected decision-makers on clemency. Pertinent examples here - where foreigners have been granted clemency by the relevant decision-maker with regularity - include rulings by the King of Thailand, the Malay Rulers and the President of Vietnam.

On the other hand, where elected decision-makers make clemency decisions (the President of Indonesia, for example, and the Singaporean Cabinet, who make the clemency decision for the Singaporean President), ${ }^{50}$ only retributive or redemptive

46 Over the past few years a notable trend in Singapore's death penalty practice has been the appearance of the so-called '14.99' charge, whereby the level of drugs that a courier is caught trafficking is artificially reduced by the prosecutor to a level fractionally below that required to invoke the mandatory death penalty (for example, 15 grams of heroin, 30 grams of cocaine, 500 grams of marijuana). Moreover, in cases where mandatory death penalty murder could be proved relatively easily, the perpetrator is sometimes charged instead with culpable homicide, equivalent to manslaughter under Singaporean law. A key interview source observed that it had become more common for charges to be reduced by the Attorney-General (public prosecutor) from around 1992 (interview with Singaporean criminal defence lawyer, Singapore (10 October 2011)). It may or may not be a coincidence that the last time a drug trafficker was granted clemency in Singapore was in 1992, see Associated Press Newswires, 2005.

47 Interview with Singaporean Human Rights lawyer (Singapore, 18 October 2011); and interview with Former Malaysian Federal Court Judge (Kuala Lumpur, 1 December 2011).

48 See Langit, 2004; Fidrus, 2006; Michelmore, 2008; Lynch, 2009: 558; and Hands Off Cain, 2013a.

49 See notes 17-18 and associated text, above.

50 See Associated Press Newswires and Yong Vui Kong v Attorney-General [2011] 1 SLR 1, [177], [180]. 
arguments for clemency have been accepted, and the governments involved have strongly emphasised that foreigners are to be treated equally to locals. By the time the case has proceeded to the clemency phase, securing clemency in the absence of any compelling case-based or individual mitigating factors will prove extremely difficult. The remaining litigation tactic here is one of delay, as I now explain.

\section{Clemency for time on death row}

With regard to the 'time on death row' limb of my research, my research suggests that extending the length of time a prisoner spends on death row will enable a variety of time-based justifications for clemency to emerge. As mentioned, these typically consist of rehabilitation, remorse and religious piety, whereas less-obvious mitigating circumstances also arise with the passing of time: old age, the 'death row syndrome', ${ }^{51}$ the ability to assist police with their ongoing investigations, terminal or family illness, and - rightly or wrongly - the opportunity for bribery. Finally, the political significance of, and public indignation regarding, particular death penalty cases will fade over time, removing often-cited barriers to clemency grants.

Here, defence tactics such as legal challenges (preferably, right from the very beginning of the case) and temporary delays to execution, even if these do not have much chance of permanent legal success (in the sense of overturning the conviction or reducing the death sentence to a non-lethal punishment) are critical in enabling timebased justifications to emerge. A prominent recent example of this approach is that of Malaysian citizen Yong Vui Kong, arrested for drug trafficking in Singapore in 2007. Vui Kong first received a temporary stay of execution in order to file an appeal out of time, and thereafter his case served as a platform to challenge the constitutionality of the mandatory death penalty for drug trafficking in Singapore in 2010, followed by the clemency decision-making process in 2011..$^{52}$ In November 2013, following legislative amendments to Singapore's death penalty laws in 2012, Vui Kong's death sentence was lifted and replaced with life imprisonment, as the prisoner had been deemed a mere courier and certified as a 'justice collaborator'. ${ }^{53}$

Finally, in Vietnam no executions could be conducted in 2012, when the European Union banned the export of drugs used in the execution process following Vietnam's switch from shooting to the lethal injection method in 2010.54 Although in 2013 Vietnam resumed executions with locally-sourced chemicals, academic analysts and human

51 See generally Hood and Hoyle, 2008: 180-183, on legal challenges around the world citing the damaging effects of time spent on death row.

52 See Save Vui Kong, 2010.

53 Bedi, 2003.

54 Babcock, 2013. 
rights NGOs are still waiting to see the effect this elongation of the time spent awaiting execution has for the more than 670 persons still waiting on Vietnam's increasingly crowded death row. ${ }^{55}$

\section{CONCLUSION}

In this paper I have demonstrated that clemency and pardon, although at first glance appearing to represent an arbitrary, unprincipled and irregular exercise of executive power, are nonetheless granted pursuant to particular patterns and decision-making strategies. It is indeed possible to explain why different countries make use of the clemency procedure more often than do others without relying solely on varying levels of governmental commitment to the death penalty as a criminal punishment.

Clemency symbolises far more than official ambivalence over capital punishment as a criminal justice policy, as its presence can coincide with both high and low rates of execution. The more information that is revealed about the way the prerogative of pardon is exercised, particularly in partially-closed systems such as the majority of Southeast Asian nations, the more clarity scholars and practitioners will have regarding the practice of capital punishment in general, given clemency's status as the crucial final avenue of appeal for a condemned prisoner: the last procedural obstacle separating life and death.

55 Hands Off Cain, 2013c; and Babcock, 2013. 


\section{REFERENCES}

Acker, JR and others (2010), 'Merciful Justice: Lessons from 50 Years of New York Death Penalty Commutations' 35 Criminal Justice Review 183.

Addruse, A (1986) 'The Respective Roles of the Pardons Board and of the Yang DiPertuan Agung', Paper presented at the Human Rights Seminar, Kuala Lumpur, 19 July.

Afrida, N (2012) 'The Ever-Raging Battle over the Death Penalty', The Jakarta Post, 19 November <www.thejakartapost.com>.

Agence France Presse (1997) 'Condemned Heroin Trafficker Gets Death Row Reprieve in Vietnam', 5 August.

Amnesty International (1984) 'Two Former Communist Leaders Under Threat of Execution in Indonesia', Al-Index ASA 21/11/84, November.

Amnesty International (1985a) 'Al Appeals for Commutation of the Trade Unionist's Death Sentence', Al-Index ACT 73/02/85, January.

Amnesty International (1985b) 'Amnesty International statement on East Timor to the United Nations Special Committee on Decolonization', AI-Index ASA 21/30/85, 13 August.

Amnesty International (1987a) 'Indonesia: Appeal for Release of Prisoners of Conscience and Commutation of Death Sentences', Al-Index ASA 21/20/87, July.

Amnesty International (1987b) 'Indonesia: The Application of the Death Penalty', AlIndex ASA 21/27/87, November.

Amnesty International (1988) 'Death by Firing Squad', 14 Inside Indonesia 2.

Amnesty International (1997) 'Against the Tide: The Death Penalty in Southeast Asia', Al-Index ASA 03/01/97, 1 January.

Amnesty International (2003) 'Socialist Republic of Viet Nam: The Death Penalty Inhumane and Ineffective', Al-Index ASA 41/023/2003, 27 August.

Amnesty International (2007) 'Asie-Pacifique : Les Condamnations à Mort pour les Infractions Liées à la Législation sur les Stupéfiants sont en Augmentation', AlIndex ASA 01/003/2007, 20 June.

Amnesty International (2011a) 'Death Sentences and Executions in 2010', Al-Index ACT 50/001/2011, March.

Amnesty International (2011b) 'When Justice Fails: Thousands executed in Asia after unfair trials', Al-Index ASA 01/023/2011, December. 
Anand, P (1996) 'His Majesty's Role in the Making of Thai History', speech delivered at the $14^{\text {th }}$ Conference of the International Association of Historians of Asia, Bangkok.

Anandan, S (2009) The Best I Could. Singapore: Marshall Cavendish.

Anckar, D (2007) 'Selecting Cases in Cross-National Political Research', 10(1) International Journal of Social Research Methodology 49.

Antara (1999) 'President Grants Clemency to 10 More Political Prisoners', 24 March.

Asia Death Penalty Blog (2008) 'Viet Nam: Life, and Death, Sentences for Drugs', 30 April <http://asiadeathpenalty.blogspot.com>.

Associated Press Newswires (2005) 'A List of Death Row Inmates in Singapore who were Granted Clemency', 2 December.

Babcock, S (2013) 'Vietnam' Death Penalty Worldwide, 5 February <www. deathpenaltyworldwide.org>.

Bampton, D (2006) 'Indonesia, Australia and the Death Penalty: Options for Australians Facing Execution in Indonesia', Honours Thesis, University of Sydney, Law School.

Bedi, RS (2003) 'Singapore Spares Yong Vui Kong the Noose, Re-Sentences Him to Life Imprisonment, 15 Strokes', The Star Online, 14 November <www.thestar. com.my>.

Botsman, D (2007) Punishment and Power in the Making of Modern Japan. Princeton, New Jersey: Princeton University Press.

Burnett, C (2002) Justice Denied: Clemency Appeals in Death Penalty Cases. Dartmouth: Northeastern University Press.

Chotibal, P (1990) 'The Royal Prerogative of Pardon in Thailand', Master of Laws Thesis, Chulalongkorn University Bangkok, Department of Law.

Coyne, R and Entzeroth, L (2001) Capital Punishment and the Judicial Process, $2^{\text {nd }}$ edition. Durham, North Carolina: Carolina Academic Press.

Cristianson, E (2013) 'Indonesia Executes Pakistani Drug Trafficker', Jakarta Globe, 18 November.

Death Penalty Information Center (2013), 'Illinois Death Row Inmates Granted Commutation by Governor George Ryan on January 12, 2003' <www. deathpenaltyinfo.org> .

Elda, E (2009) 'Pengaturan Pidana Mati sebagai Pidana Pokok yang Bersifat Khusus dan Alternatif dalam Rancangan Kitab Undang-Undang Hukum Pidana', PhD Thesis, Jakarta, University of Indonesia, Faculty of Law. 
Faruqi, S (2008) Document of Destiny: The Constitution of the Federation of Malaysia. Selangor, Malaysia: Star Publications.

Fidrus, M (2006) 'Tough Sentencing Not Stopping Drug Crime, Judge Says', The Jakarta Post, 31 May.

Glasius, M (1999) Foreign Policy on Human Rights: Its Influence on Indonesia under Soeharto. Antwerp: Hart.

Handley, PM (2006) The King Never Smiles. New Haven, Connecticut: Yale University Press.

Hands Off Cain (2013a) 'Indonesia - Retentionist' <www.handsoffcain.info>.

Hands Off Cain (2013b) 'Singapore - Retentionist' <www.handsoffcain.info>.

Hands Off Cain (2013c) 'Vietnam - Retentionist' <www.handsoffcain.info>.

Hood, R and Hoyle, C (2008) The Death Penalty: A Worldwide Perspective. $4^{\text {th }}$ edition.

Oxford: Oxford University Press.

Hor, M (2004) 'The Death Penalty in Singapore and International Law', Singapore Year Book of International Law 105.

Human Rights Watch (2009) 'End the Death Penalty for Drug-Related Offenses', 22 June <www.hrw.org>.

Human Rights Watch (2013) 'Indonesia: First Execution in 4 Years a Major Setback', 21 March <www.hrw.org>.

Imparsial (2010) Inveighing Against Death Penalty in Indonesia. Jakarta: Imparsial.

The Jakarta Post (1998) 'Question about Amnesty', 27 July.

Johnson, DT (2013) 'The Jolly Hangman, the Jailed Journalist, and the Decline of Singapore's Death Penalty', 8 Asian Criminology 41.

Johnson, DT and Zimring, FE (2009) The Next Frontier: National Development, Political Change, and the Death Penalty in Asia. Oxford: Oxford University Press.

Kershaw, R (2001) Monarchy in South-East Asia: The Faces of Tradition in Transition. London: Routledge.

Kohli, A et al; (1995) 'The Role of Theory in Comparative Politics: A Symposium', 48(1) World Politics 1.

Kontras (2010) 'Execution Carried Out; Death Row Inmates in Indonesia; Indonesian Legislation/Law Applying the Death Sentence' <www.kontras.org>.

Langit, R (2004) 'Indonesia: End Death Penalty, Rights Groups Urge', Inter Press Service, 6 October <www.highbeam.com>. 
Lee, SK (2006) 'Prosecutorial Discretion and Clemency in the Singapore Criminal Justice System', in Teo Keang Sood (ed), Singapore Academy of Law Conference 2006: Developments in Singapore Law Between 2001 and 2005. Singapore: Academy Publishing.

Lev, D (1999) 'The Criminal Regime: Criminal Process in Indonesia', in Vicente L Rafael and Rudolf Mrazek (eds), Figures of Criminality in Indonesia, the Philippines and Colonial Vietnam. Ithaca, New York: Cornell University Press.

Lev, D (2011) No Concessions: The Life of Yap Thiam Hien, Indonesian Human Rights Lawyer. Seattle: University of Washington Press.

Lijphart, A (1971) 'Comparative Politics and the Comparative Method', 65(3) The American Political Science Review 682.

Lynch, C (2009) 'Indonesia's Use of Capital Punishment for Drug-Trafficking Crimes: Legal Obligations, Extralegal Factors, and the Bali Nine Case', 40 Columbia Human Rights Law Review 523.

McGregor, G (2004) 'Cards Stacked against Canadians: Vietnam has Dramatically Increased Death Sentences for Drug Trafficking', The Ottawa Citizen, 7 January.

Michelmore, K (2008) 'Bali Bombers Deaths "Soon as Possible”', The Australian, 21 July.

Murray, A (1991) 'Notes from Cipinang Prison', 27 Inside Indonesia 19.

The Nation (2001) 'Chavalit Honours Anti-Drug Efforts', 26 June.

Nelken, D (2011) 'Why Compare Criminal Justice', in Mary Bosworth and Carolyn Hoyle (eds), What is Criminology? Oxford: Oxford University Press.

Neuman, WL (2005) Social Research Methods: Qualitative and Quantitative Approaches. $6^{\text {th }}$ edition. Boston: Allyn \& Bacon.

Neumayer, E (2008) 'Death Penalty: The Political Foundations of the Global Trend towards Abolition', 9 Human Rights Review 241.

Nicholson, P and Truong, K (2008) 'Drugs Prosecutions in Vietnam: The Modern Propaganda Trial', 34 Monash University Law Review 430.

Osman, N (2010) 'Malaysia Asked to Spare 3 Traffickers Facing Death', Jakarta Globe, 19 September.

Palmer, LJ (2001) Encyclopedia of Capital Punishment in the United States. London: McFarland.

Perry, N (2009) 'Winning a Battle, Losing the War', 96 Inside Indonesia <www. insideindonesia.org>.

Ravi, M (2005) Hung at Dawn. Singapore: Orion Books. 
Richardson, M (1992) 'Malaysia Prepares to Strip Sultans of their Immunity', International Herald Tribune, 15 December.

Riza, M and Kurniawan, I (2010) 'Menuju Tiang Gantung Malaysia', Viva News, 27 August <http://us.sorot.news.viva.co.id>.

Saragih, B (2012) 'SBY Approves Clemency for 19 Drug Convicts', The Jakarta Post, 17 October.

Save Vui Kong (2010) 'Vui Kong's Journey', <http://savevuikong.blogspot.co.uk/>.

Schabas, W (2004), 'Conjoined Twins of Transitional Justice - The Sierra Leone Truth and Reconciliation Commission and the Special Court', 2 Journal of International Criminal Justice 1082.

Scott, AW (1952) 'The Pardoning Power', 284 Annals of the American Academy of Political and Social Science 95.

Skocpol, T and Somers, M (2006) 'The Uses of Comparative History in Macrosocial Inquiry', in Alan Sica (ed), Comparative Methods in the Social Sciences, vol 2. London: SAGE Publications.

Strange, C (1996) 'Introduction', in Carolyn Strange (ed), Qualities of Mercy: Justice, Punishment and Discretion. Vancouver: University of British Columbia Press.

Talib, NH (1989) 'The Powers and Functions of the Pardons Board in Malaysia - A Review', Master of Laws Dissertation, University of Malaya.

TAPOL (1980) 'The Background to their Years of Agony', 98 TAPOL Bulletin 3.

TAPOL (1995) '1965 Tapols: Amnesty the Only Way', 130 TAPOL Bulletin 2.

van Oosten, K (2008) 'Kamma and Forgiveness with some Thoughts on Cambodia', 37 Exchange 237.

\section{INTERVIEWS}

Interview with American Academic Expert on Capital Punishment (Hong Kong, 7 November 2011)

Interview with Australian Academic Expert on Indonesia (Telephone interview, 30 January 2013)

Interview with Australian Academic Expert on Thailand (Canberra, 16 September 2009)

Interview with Former Malaysian Federal Court Judge (Kuala Lumpur, 1 December 2011)

Interview with London-based Indonesian Human Rights Activist (London, 22 August 2011) 
Interview with Senior Indonesian Human Rights Lawyer (Jakarta, 11 April 2013) Interview with Singaporean Criminal Defence Lawyer (Singapore, 10 October 2011) Interview with Singaporean Human Rights Lawyer (Singapore, 18 October 2011) Interview with Thai Human Rights Activist (Bangkok, 7 September 2012) Interview with Thai Law Professor (Bangkok, 14 September 2012) Interview with Thailand Department of Corrections Staff (Bangkok, 24 September 2012)

\section{CASES AND LEGISLATION}

Constitution (Amendment) Act 1994 (Malaysia)

Constitution of Indonesia 1945

Constitution of Malaysia 1963

Constitution of Singapore 1965

Penal Code 1999 (Vietnam)

Law No 14 of 1985 on the Supreme Court (Indonesia)

Law No 22 of 2002 on Clemency (Indonesia)

Law No 3 of 1950 on Clemency (Indonesia)

Law No 8 of 1981 on Criminal Procedure (Indonesia)

Presidential Decree No 16 of 1963 on the Extraordinary Military Tribunal (Indonesia) Yong Vui Kong v Attorney-General [2011] 1 SLR 1 (Singapore Court of Appeal) 
CILIS 
ALC BRIEFING PAPER 


\section{CILIS Policy Paper Series}

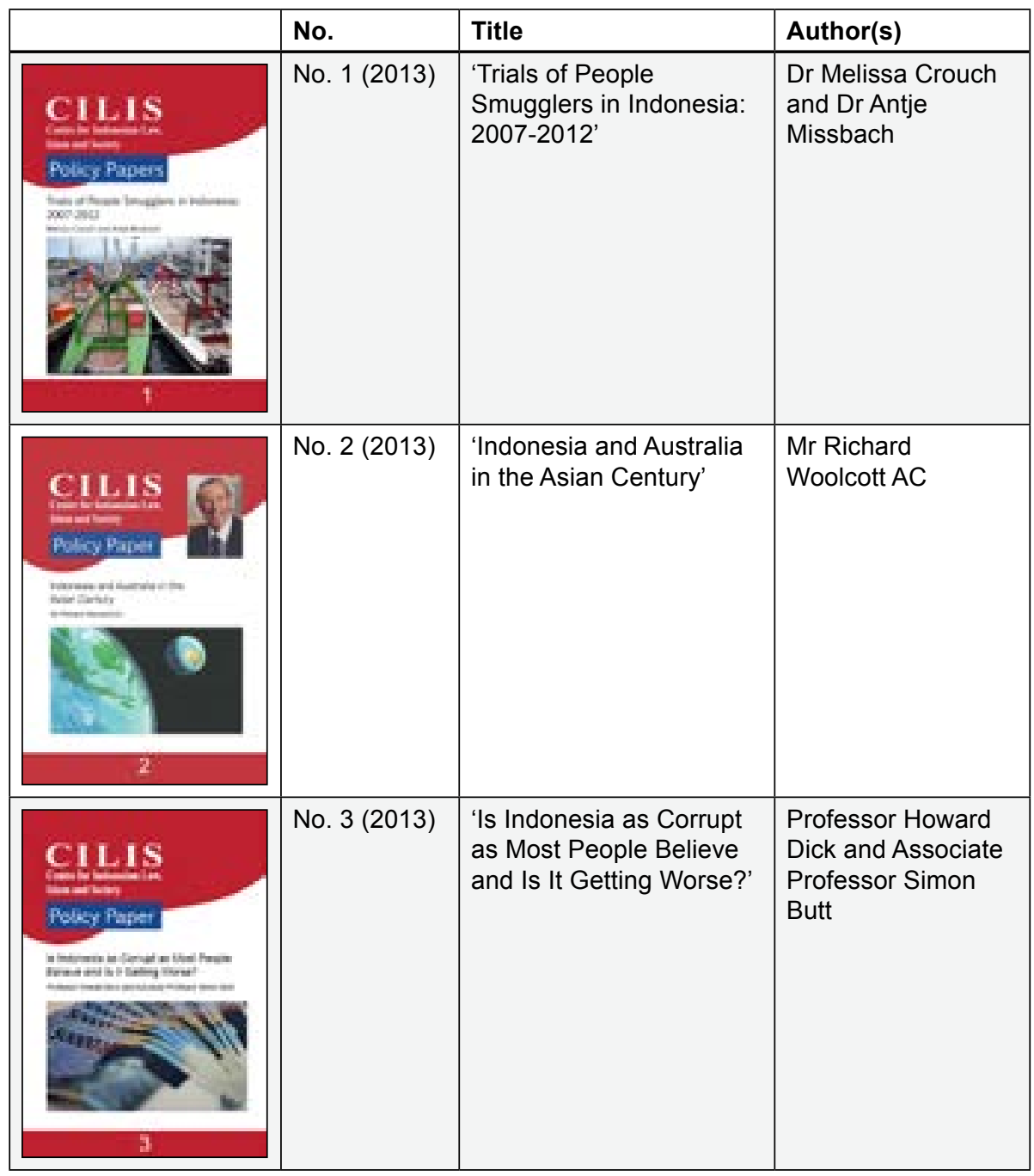

The CILIS Policy Paper Series is freely available for download at http://www.law.unimelb.edu.au/cilis/research/centre-publications/cilis-policy-papers. 
ALC BRIEFING PAPER 


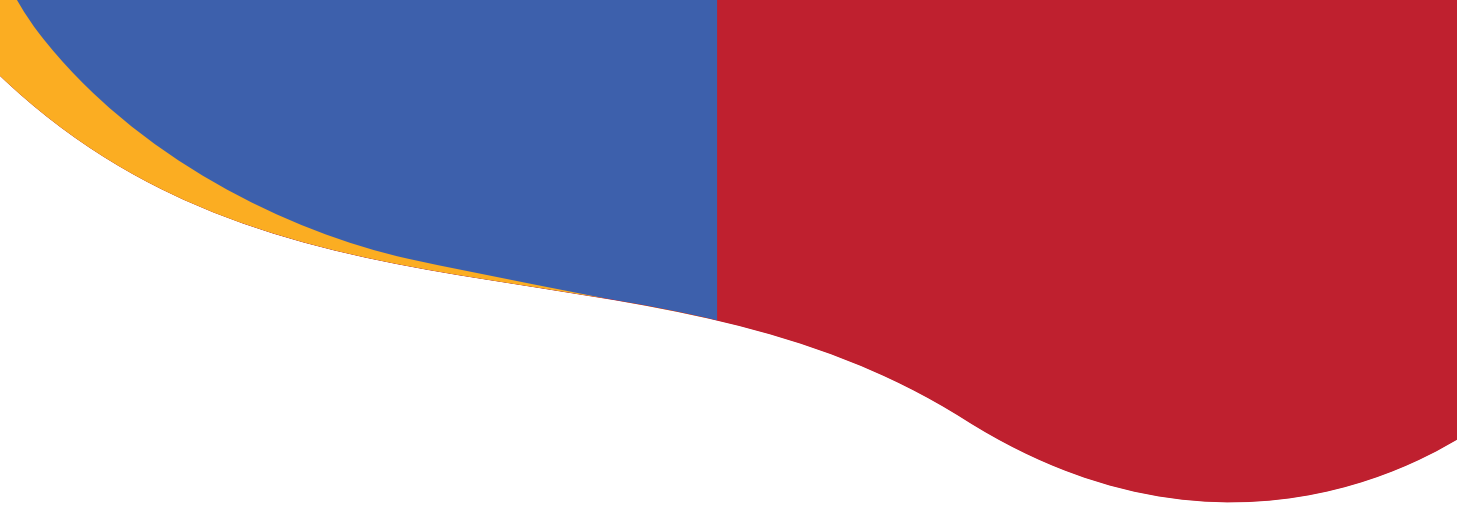

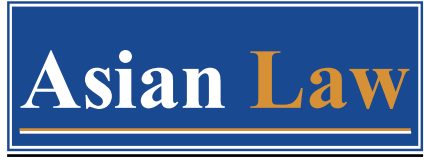

Melbourne LaW SchOOL

\section{Centre for Indonesian Law, Islam and Society \&}

\section{Asian Law Centre}

Melbourne Law School

The University of Melbourne

CILIS: www.law.unimelb.edu.au/cilis | law-cilis@unimelb.edu.au

ALC: www.law.unimelb.edu.au/alc | law-alc@unimelb.edu.au 


\section{University Library}

\section{- M M I N E R VA A gateway to Melbourne's research publications}

Minerva Access is the Institutional Repository of The University of Melbourne

Author/s:

PASCOE, D

Title:

Clemency in Southeast Asian Death Penalty Cases

Date:

2014

Citation:

PASCOE, D. (2014). Clemency in Southeast Asian Death Penalty Cases. Asian Law Centre, University of Melbourne.

Persistent Link:

http://hdl.handle.net/11343/258394 